\title{
Writer Identity Construction in MSc. Students of Engineering
}

\author{
Masood Monjezi ${ }^{1, *}$ \\ ${ }^{1}$ Department of Basic Sciences and English Language, Ahvaz Faculty of Petroleum, Petroleum University of \\ Technology, Ahvaz, Iran \\ *Correspondence: Department of Basic Sciences and English Language, Ahvaz Faculty of Petroleum, Petroleum \\ University of Technology, Ahvaz, Iran. Tel: 98-916-304-1396. E-mail: m.monjezi@put.ac.ir
}

Received: May 28, 2021

Accepted: July 11, $2021 \quad$ Online Published: July 19, 2021

doi:10.5430/ijelt.v8n2p22

URL: https://doi.org/10.5430/ijelt.v8n2p22

\begin{abstract}
Writing in academia is not only a way for students to acquire knowledge and skills, but also a process through which they construct author/researcher identity. This study aims to explore how twenty MSc. students construct their identity as writers of research papers. The students in this study received genre-based writing instructions on writing research papers during their writing course in the first semester of university. They wrote four papers during the semester, and the researcher provided feedback to their papers. Then, they were interviewed individually in order to find out how they reacted to the instructions, the writing process, and the feedback provided by the teacher. In addition, they were requested to write a reflective piece of writing about what they experienced including their emotions, thoughts and opinions about writing an academic paper before and after the course. Two types of analyses were made. Firstly, their sample research papers were examined during the course to see if there were improvements in the areas where feedback was provided. Secondly, the interviews and reflective pieces of writing were subjected to content analysis in order to extract themes. The examination of the papers revealed that the feedback provided by the teacher was effective as the writings improved in the areas where feedback was given. The thematic analysis resulted in two major themes of Affect and Attitude and the Need for Adaptation. An important implication of this study was the role feedback played in helping student/researchers to develop their identity in writing.
\end{abstract}

Keywords: student/researcher, feedback, identity construction

\section{Introduction}

Writing is an important skill to learn in graduate and post-graduate education in Iran (Kotamjani \& Hussin, 2017). Students are part of research projects, and they are also mostly responsible for writing and publishing these studies. Most of these students, however, are insufficiently proficient at English language and the situation is even worse when they need to write (Dehghan \& Razmjo, 2017).

There are three major reasons for students to want to write research papers. First, continuing education in $\mathrm{PhD}$ depends largely on showing a competence in writing research papers while being a student in MSc Program. Second, being able to defend dissertations and graduate with a $\mathrm{PhD}$ requires the students to publish at least one ISI paper (Cargill et al, 2018; Huang, 2010; Li, 2016). This requirement could be more than one ISI and several non-ISI publications depending on the institutions, faculties or departments. Third, applying to universities abroad also requires students to have some published articles in their CVs to demonstrate their research skills and abilities.

These demands coupled with lack of English writing skills have resulted in several problems. First, some students might have no other choices but plagiarize whole or at least part of their papers (Amiri \& Razmjoo, 2016; Perkins et al, 2018). In addition, some others might resort to Google Translate which can help, but since they are not able to edit translations, their efforts usually lead to papers of low quality (Groves, \& Mundt, 2015). Moreover, others try to find a translator and have him/her translate their papers which can result in poor translations due to unfamiliarity of translators with the jargon of the field and the writing standards which should be followed.

Universities in Iran offer ESP courses in MSc; however, the main focus of these courses is on reading, vocabulary, language structures and translation. These courses are also mostly taught using Grammar Translation Method (GTM). 
Therefore, it can be safely stated that university students are not prepared for what they are required to perform. The poor preparations and lack of proper English writing background among students will cause stress, disappointment, and deception.

The purpose of this study is to address these problems with a particular focus on MSc students in two ways. First and foremost, the researcher attempts to draw the attention of higher education institutions in Iran to this problem. In addition, a solution to this problem will be proposed. The solution might be far from perfect; however, it can be a step forward towards a better understanding the problem and collaboration for dealing with it.

The literature now shows that in order to become an effective writer, one should be able to adopt proper writer identity (Abbasi, et al, 2006). It can be assumed that instructions on Swalesian move structures and helping students to understand the components that publishing gatekeepers expect the writers to follow (Adnan, 2009) and giving sufficient amount of feedback on vocabulary, sentence structures and move structures can contribute to improvements in writing and also help MSc writers to form writer identity (Bitchener \& Ferris, 2012).

On the other hand, feedback has been the focus of a wide spectrum of scholarly attention. Some studies showed no improvements resulted from feedback (Truscott, 1996, 1999, 2004, 2007, 2009; Bitchener, Young \& Cameron, 2005 Farid \& Samad, 2012; Van Beuningen, De Jong, Kuiken, 2012) while several studies show that feedback is in fact effective (Ellis, 2007; Ferris, 1997, 2014; Ferris \& Helt, 2000; Hyland, 2013; Lalande, 1982; Mahfoodh \& Pandian, 2011; Robb et al., 1986; Robinson, Pope, \& Holyoak, 2013; Russel \& Spada, 2006; Semke, 1984; Sheen, 2007).

Research on feedback shows that it can contribute to shaping writer's identity (Botelho de Magalhaes, Cotterall \& Mideros, 2019; Cheung et al., 2016; Choi, 2015; Cooper and Davis, 2016; Cotterall, 2015; Ivanič, 1998). Gomez-Estern et al. (2010) argued that identity is shaped by mediation of cultural tools and in interaction taken place socially. Identity comes from the relationships of individuals in different cultural groups. It is also formed by the cooperation and struggle the individual has with groups and the members. Feedback can facilitate membership of the new researcher/writer by providing them opportunities to practice being a member and meet expectations (Ivanič, 1998).

Therefore, the aim of this study is to examine whether feedback can improve engineering students' academic writings as previous studies led to controversial results (Truscott, 1996, 1999, 2004, 2007, 2009; Ferris, 1997, 2014; Ferris \& Helt, 2000; Bitchener, Young \& Cameron, 2005 Farid \& Samad, 2012; Van Beuningen, De Jong, Kuiken, 2012; Ellis, 2007; Hyland, 2013; Lalande, 1982; Mahfoodh \& Pandian, 2011; Robb et al., 1986; Robinson, Pope, \& Holyoak, 2013; Russel \& Spada, 2006; Semke, 1984; Sheen, 2007). In addition, it also attempts to explore how feedback given to their writings might contribute to their identity construction.

The following research questions in fact initiated this study:

RQ1: Can feedback on sentence structures and Swalesian move structure improve engineering students' academic writings?

RQ2: How can feedback given to academic writings of engineering students enhance writer/researcher identity?

\section{Methodology}

This study aimed at exploring how twenty MSc. students of petroleum, chemical and automation engineering constructed their identities as researchers/writers.

\subsection{Participants}

In this study, there were twenty participants who were students of petroleum (nine), gas (seven) and automation (four) engineering in Ahvaz Faculty of Petroleum of Petroleum University of Technology (Table 1). These students studied their Bachelors' in different universities all over the country. There were four female and sixteen male students. Their age ranged from twenty three to thirty one. Their level of English was lower intermediate according to the placement test administered in the first session of the class. Each participant is presented with a number to keep their anonymity confidential. In addition, written consents were approved by the participants to see if they are willing to participate in this study. 
Table 1. Participants

\begin{tabular}{|c|c|c|}
\hline Participants & Age & Major \\
\hline 1 & 25 & Petroleum Engineering \\
\hline 2 & 24 & Petroleum Engineering \\
\hline 3 & 23 & Petroleum Engineering \\
\hline 4 & 26 & Petroleum Engineering \\
\hline 5 & 25 & Petroleum Engineering \\
\hline 6 & 25 & Petroleum Engineering \\
\hline 7 & 26 & Petroleum Engineering \\
\hline 8 & 23 & Petroleum Engineering \\
\hline 9 & 24 & Petroleum Engineering \\
\hline 10 & 24 & Gas Process Engineering \\
\hline 11 & 24 & Gas Process Engineering \\
\hline 12 & 23 & Gas Process Engineering \\
\hline 13 & 25 & Gas Process Engineering \\
\hline 14 & 29 & Gas Process Engineering \\
\hline 15 & 31 & Gas Process Engineering \\
\hline 16 & 28 & Gas Process Engineering \\
\hline 17 & 24 & Automation \\
\hline 18 & 25 & Automation \\
\hline 19 & 28 & Automation \\
\hline 20 & 26 & Automation \\
\hline
\end{tabular}

\subsection{Procedure}

Upon entering the university in their first semester, students of Ahvaz Faculty of Petroleum of Petroleum University of Technology are assigned different courses relevant to their majors and six hours of English including two hours of listening and speaking in the laboratory and four hours of writing.

The students in this study received genre-based writing instructions on writing research papers during their writing course in the first semester. The writing instructions included 56 hours of instruction in fourteen weeks. During the course, the instructor taught sentence structures, development of paragraphs, and genre based instructions of the Swalesian moves in a research paper.

The participants were required to write four assignments focusing on Introduction, Methodology, Results and Discussion which are integral parts of a research paper according to Swales $(1990,2004)$. The instructor provided feedback in written and spoken forms to the participants both in classroom and his office. The feedback was intended to deal with choice of vocabulary, sentence structures, move structures and the linguistic devices required to perform the necessary moves, and finally the overall quality of the paper.

\subsection{Date Collection}

The approach to data collection and analysis in this study consisted of quantitative and qualitative methods. In the quantitative data collection, the data on the amount of feedback to each of the four series of papers were analyzed by calculating the frequency of the feedback to each set of papers in order to find out how the participants improved over time. Furthermore, each paper was scored according to the assessment criteria devised by test developers of IELTS (Uysam 2010). These criteria include Task Achievement, Coherence and Cohesion, Lexical Resource, and Grammatical Range and Accuracy (IELTS). Afterwards, each paper received a score from one to nine according to IELTS scoring system. These papers were first scored by the researcher; then, in order to establish the inter-rater reliability, they were scored by a colleague too. The figure 0.86 was estimated for the inter-rater reliability of scores 
to these papers using Cronbach Alpha. At the time of this study, the researcher had over 14 years of experience in teaching IELTS and other advanced writing courses at university.

In order to find out how much improvements each participant made during the course of instruction, a paired samples t-test was utilized and the first writing assignments were compared to the fourth which were about three months apart from each other.

The mixed method adopted here enjoyed a qualitative section which involved three sets instruments for data collection. The instruments for collecting data include one semi-structured interview for each participant (twenty in total), two focus groups (one for each ten students to allow enough time and room for discussion) and reflective pieces of writings. The participants were expected to speak Persian in semi-structured interviews and focus groups and write Persian in their reflective writings. The comments needed for the result section then were translated into English communicatively to represent the original intentions. Efforts were made to keep the style of the participants in translation. The data acquired from these were then thematically analyzed. In semi-structured interviews, there were twelve questions starting with the participants' background and continuing into education, writing, change and ending with feedback. The same topics were covered both in focus groups and reflective writings; however, the questions in the semi-structured interviews were more personal as the interviews were conducted by the teacher in his office, and each participant was interviewed individually. On the other hand, the questions in focus groups with ten participants in each meeting concerned more the social nature of the issue, while touching upon the topics raised in the interviews as well. In the reflective writing, the participants were assigned the same topics to avoid spontaneity in responses and allow reflection by the participants in order to elicit deeper aspects requiring reflection. These different tools were used in this study in order to triangulate and improve qualitative validity.

\subsection{Data Analysis}

After collection of the data, thematic analysis was performed which involved reiterative reading of the data in order to find out the themes relevant to the effects of feedback on how they constructed their identity.

In addition, the data were also read by the researcher and another colleague in order to make sure the findings of the codes and then themes were reliable. The consistency in this part meant that the researcher and his colleague coded one idea using any semantically related words. Afterwards, a series of lengthy discussions of the codes was conducted in order to find out why the researcher and his colleague selected the codes until an agreement was reached; however, when two codes were extracted which were totally different, and they were not able to agree, the code or theme was ignored. The codes were counted and the correlation coefficient of inter-rater reliability was estimated at 0.73 which seems acceptable.

\section{Results}

In this study, the mixed method adopted generated two different sets of data. The first set concerned the quantitative section, and the second part concentrated on the qualitative set.

\subsection{Quantitative Results}

In the quantitative section, Figure 1 shows the amount of feedback given to the assignments decreased over the course of time, which suggests improvement of the writings in all three major areas where feedback was given, namely choice of vocabulary, sentence structure, and move structure. The choice of vocabulary received the highest amount of feedback which was more than twice the other areas. It was also higher in the second round of assignments; however, their last assignments received the lowest amount of feedback compared to the other two areas; namely, sentence structure and move structure. The last set of assignments received fewer items of feedback. Move structure received more feedback than did sentence structure; however, at the end they received almost the same amount. The highest improvement, according to the observed reductions in the amount of feedback, could be seen in choice of academic vocabulary, the improvement observed was not huge which suggest that learning sentence structure is not as easy as the other areas. Also, engineering students in this study showed higher improvement in learning move structure than the sentence structure. 


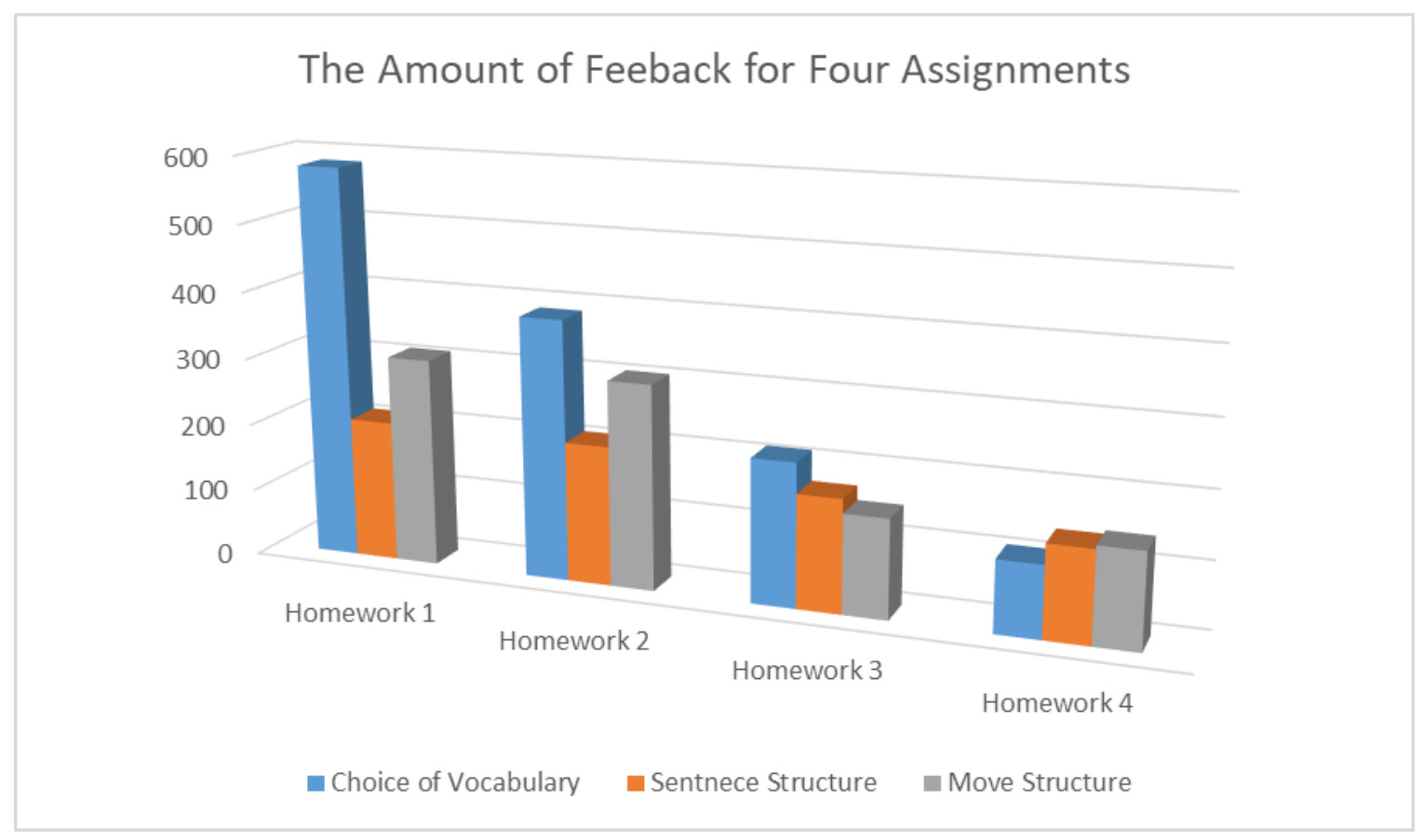

Figure 1. The Amount of Feedback for Four Assignment

Table 2. T-Test

\begin{tabular}{|c|c|c|c|c|c|c|c|c|c|c|c|}
\hline & & & \multicolumn{6}{|c|}{ Paired Differences } & \multirow[t]{3}{*}{$\mathrm{t}$} & \multirow[t]{3}{*}{$\mathrm{df}$} & \multirow{3}{*}{$\begin{array}{l}\text { Sig. } \\
\text { (2-tailed) }\end{array}$} \\
\hline & & & \multirow[t]{2}{*}{ Mean } & \multirow[t]{2}{*}{$\begin{array}{l}\text { Std. } \\
\text { Deviation }\end{array}$} & \multirow[t]{2}{*}{$\begin{array}{l}\text { Std. } \\
\text { Mean }\end{array}$} & \multirow[t]{2}{*}{ Error } & \multicolumn{2}{|c|}{$\begin{array}{l}95 \% \text { Confidence Interval } \\
\text { of the Difference }\end{array}$} & & & \\
\hline & & & & & & & Lower & Upper & & & \\
\hline Pair & v1 & $\mathrm{v} 2$ & -1.80000 & .78472 & & .17547 & -2.16726 & -1.43274 & -10.258 & 19 & .000 \\
\hline
\end{tabular}

Table 2 presents the results of the t-test on the overall quality of the assignments scored by the researcher and his colleague. As can be observed in the table, there is a meaningful difference between the quality of the first and the last assignments which means instructions on choice of academic vocabulary, sentence structure and move structure have enabled the engineering students to improve their writing quality.

\subsection{Qualitative Analysis}

\subsubsection{Thematic Analysis}

There were three means of collecting data in the qualitative section of this study; namely, semi-structured interviews, focus groups and reflective pieces of writings. The data collected from these instruments included 17258 words from semi-structured interviews, 7380 words from focus group, and 10247 words from reflective writings, 34885 words in total. These themes were the result of reiterative readings of the data. After extraction of the themes, it was observed by the researcher and his colleague that the categories could be classified into two major themes.

Two major themes including affect and attitude and the need for adaptation emerged after analysis of the data as presented in Table 3. The themes, affect and attitude, were the result of lumping together the categories related to affect, emotions and attitudes. Below some of the participants comments are presented.

Participant 3: "I was very anxious when you (the instructor) started giving feedback. At the end of the session, I felt disappointed. But things got better because I knew where I had more problems. In the second paper I had fewer problems honestly, still there were lots of mistakes, but much better than the first one. It got better and better. Then I felt more hopeful. But I will never forget the first time."

Participant 17: "I felt I would not be able to ever write a paper. I did not hand in a paper in the first few weeks. It was beyond my abilities. But when I saw changes and improvements in others, I started writing. 
But it was very difficult. The first paper was slaughtered by the teacher. Then I went to my room and inspected the errors and the corrections and the explanations. I felt like a fool. The next paper was much better and less red and in the third paper I felt I am finally writing."

As can be seen in the comments above, participant 3 went from anxiety and disappointment while receiving feedback to hope and her writing was much better. In addition, participant 17 started from absolute disbelief in being able to write to improvements and to feeling of being able to write.

The theme adaptation is composed of several categories as presented in Table 3. Some comments are presented below.

Participant 9: "I think I need to change my way of thinking about writing. Or I will not be able to publish."

Participant 13: "I should write like the papers that are published. Now I write in a way that is different and it is not good."

Participant 4: "I thought I knew a lot about papers but when I started to write seriously I realized I did not know how to write in an acceptable way. But the teacher wanted us to change many things in our writings. Also our teacher analyzed some papers and we realized we need to change. Journals demand high quality, so we have to write with a higher quality than now."

Participant 20: "I think English speakers can write much better than us. It is not fair to compare us with English or American speakers. They are native speakers."

Feedback helps participants of this study to improve and showed them that it is possible to write as a result of the improvements, they felt more confident. In addition, giving them feedback helps them realize what the journals expect them to do in their papers in order to be published. In fact, feedback helps the participants to restructure on three levels which will be presented in the discussion.

Table 3. The Result of Thematic Analysis

\begin{tabular}{ll}
\hline The themes extracted from the data & \\
\hline Theme 1: Affect and Attitude & Theme 2: The Need for Adaptation \\
- Anxiety vs. Hope & $-\quad$ The need to change \\
- Despair vs. Satisfaction & $-\quad$ Similar to published papers \\
- Challenge vs. Ease & $-\quad$ Students' expectations vs. Teachers and Journals' expectations \\
& $-\quad$ Us (non-native writers) vs. Them (native writers) \\
& - Feedback \\
\hline
\end{tabular}

\section{Discussion}

\subsection{The Effectiveness of Feedback}

The findings of previous studies on feedback have been largely controversial. On the one hand, some studies have found that feedback was effective in improving different aspects of writing: accuracy over time (Bitchener, 2008; Russel \& Spada, 2006), fluency (Chandler, 2003), writing conventions (Hyland, 2013), structure complexity (Robb et al., 1986), and use of articles (Sheen, 2007); on the other hand, there are studies that reported writings of students showed no improvement as a result of feedback (Bitchener, Young \& Cameron, 2005; Ellis, Sheen, Murakami \& Takashima, 2008; Farid \& Samad, 2012; Ferris \& Roberts, 2001; Kepner, 1991; Polio et al., 1998; Truscott, 1996, 1999, 2007 \& 2009; Van Beuningen, De Jong, Kuiken, 2012). The results of the quantitative section of this study were consistent with studies which argued for effectiveness of feedback. As mentioned in the result section, feedback was useful to participants on different levels. The first level is an affective level where they learnt that errors are natural in learning process and they should not be embarrassed about making them. They realized they should use what they learn from errors to their advantage. The second is that learners can cognitively improve by restructuring (McLaughlin, 1990). Restructuring provides the opportunity for qualitative changes in their interlanguage. The qualitative changes are changes in the ways of representation of knowledge in mind and how the knowledge represented is used. In addition, the shift from exemplar-based to rule-based learning is provided by representational changes. 


\subsection{Feedback and Identity}

The third level influencing participants concerns culture and community of practice. Participants will learn about the expectations required by the gatekeepers to allow new members enter the community of practice. When they learn what they are expected to do to become a member, they will do that, but when they are not aware of those requirements, the membership process becomes frustrating and fruitless.

According to Gomez-Estern et al. (2010, p. 232), "Identity is generated in social interaction, mediated by cultural instruments, and contextually situated." That is, individuals need to define themselves because they are immersed in social settings in which there is another (individual, social group, or culture). Cultural identity arises from the relationships that individuals maintain with cultural groups, with which they struggle and cooperate. The themes found in this study can be related to key terms of the above statement; for example, the category of "Students' Expectations vs. Teachers' and Journals' Expectations" can be represented, contextually situated, immersed in social settings, the relationships between individuals maintained with cultural groups. The themes "affect and attitude (Anxiety vs. Hope, Despair vs. Satisfaction, Challenge vs. Ease) and the need to change" can be observed in the "struggle" of the learners to change and adapt and cooperation of the participants with the teacher and the journals when writing and publishing papers.

Participants try to construct their identity as they "need to define themselves because they are immersed in social settings in which there is another (individual, social group, or culture)" which can also be shown by "Us (non-native writers) vs. Them (native writers)".

Feedback plays an important role in construction of learners' writer identity because it is socially and culturally situated and mediated (Botelho de Magalhaes; Cotterall \& Mideros, 2019; Cheung et al., 2016; Choi, 2015; Cooper and Davis, 2016; Cotterall, 2015; Ivanič, 1998). In addition, it facilitates the process of adaptation and reduces the intensity of the struggle as writing learners learn to accommodate demands and expectations of the writing task in the target language. Moreover, it involves cooperation between teachers and journals which might lead to a decrease in the struggle between "Us (non-native writers) vs. Them (native writers). This means that when the teacher analyzes the published papers for students and after students have realized what and how they are expected to write, the teacher provides feedback to their papers which is similar to the linguistic and rhetorical structures demanded by journals' standards.

According to Clark \& Ivanič (1997), "an academic writer identity is made present in the writing in the form of various "selves," including autobiographical, authorial and/or discoursal." These selves are utilized according to the writer, the task, and sociocultural or sociopolitical aspect (Ivanič, 1998). The writing teachers can create the task, and sociocultural or sociopolitical aspects, and this way s/he can influence the affect and attitude of the writing learners. The teachers can also pave the way for the learners to go through adaptations. In addition to the instructions and the tasks assigned by the teachers, feedback can reinforce the way writing learners view what they are learning. The sociocultural and sociopolitical aspects of the academic papers are created by the professors teaching the relevant major, the journals (the gatekeepers) and the writing teachers attempt to duplicate the environment. The tasks designed, the sociocultural and sociopolitical aspects in reality and the ones teachers attempt to recreate in class and the feedback in particular will enable the learners to acquire authorial and discoursal selves (Ivanič, 1998). Also, the experience gained during a course designed this way will function as autobiographical self.

The instruction on move structure helps students to learn to think more systematically and critically. Instructions on moves help raise learners' awareness of how academic papers are structured and the demands they make on the writers' side for critical and systematic thinking (Adnan, 2009). The writing learners need to evaluate previous literature, to be logical in designing methodology and to be consistent in the presentation of their findings and discussion. All through this, feedback plays a significant role in making the learners more critical because it refocuses the learners on where they were not evaluative, critical and systematic.

Learning about the move structure, in fact, is the part where the writers learn about the way they should interact with the community of practice. When they learn about the moves they come to know that the members of community of practice write in a special way and they discover that if they are going to communicate with them they have to write similarly which might seem like they are pressed to do so which can be observed in the themes discovered in this study. This initial pressure (challenge) continues until they find their own voice and identity.

On the other hand, by learning moves and rhetorical structures, beginning learners will have a point of reference to compare their written works with. It is useful because there are frameworks to resort to when they intend to evaluate their written works against the standards. 


\section{Conclusion}

This study has shown that training and creating an environment for graduate students to learn and develop their writing will be useful. In Iranian universities, students feel compelled and are under tremendous pressure to write without preparations which can have serious consequences mentioned in Introduction. In order to avoid these negative consequences and help contribute to the research communities, students should be assisted with their writings rather than being left alone.

Graduate students should be able to examine published papers and learn the demands and the standards of relevant journals before they are demanded to write and publish. They should also be given feedback on different aspects of writing to improve their capacities. Feedback played a crucial role in helping student/researchers to develop their identity in writing. Feedback is actually an important way of reconstructing academic writing, the future sociocultural expectations and cognitive realities that student/researchers encounter in the future.

However, despite overall importance, to be efficient there are different factors to be considered such as affect, proper conditions for feedback, the most effective type of feedback for academic circumstances which might lead to publication. Future studies can focus on the aspects above particularly the long term effects of feedback and its effectiveness on publication which requires a longitudinal study.

In conclusion, there are two major implications to this study. One implication for EAP and ESP teachers of graduate schools is to integrate writing research papers in their syllabi in order to contribute to research publication of the universities. The other implication is for universities to consider EAP and ESP courses more seriously and take necessary measures in order to develop courses and syllabi which include academic writing and publishing. An important point, however, is that graduate students ought not to start writing before they are properly trained and prepared; otherwise, tremendous amounts of anxiety, pressure and despair will inflect student/researchers on graduate levels. I believe that early pressure to write will damage the process of writer/researcher identity construction. Student/researchers need a safe environment to try to generate their writings and should be provided with sufficient and right feedback to grow their identity.

\section{References}

Abasi, A. R., Akbari, N., \& Graves, B. (2006). Discourse appropriation, construction of identities, and the complex issue of plagiarism: ESL students writing in graduate school. Journal of Second Language Writing, 15(2), 102-117. https://doi.org/10.1016/j.jslw.2006.05.001

Adnan, Z. (2009). Some potential problems for research articles written by Indonesian academics when submitted to international English language journals. The Asian EFL Journal Quarterly, 11(107).

Amiri, F., \& Razmjoo, S. A. (2016). On Iranian EFL undergraduate students' perceptions of plagiarism. Journal of Academic Ethics, 14(2), 115-131. https://doi.org/10.1007/s10805-015-9245-3

Bitchener, J. (2008). Evidence in support of written corrective feedback. Journal of Second Language Writing, 17, 102-118. https://doi.org/10.1016/j.jslw.2007.11.004

Bitchener, J., \& Ferris, D. R. (2012). Written corrective feedback in second language acquisition and writing. Routledge. https://doi.org/10.4324/9780203832400

Bitchener, J., Young, S., \& Cameron, D. (2005). The Effects of Different Types of Corrective on ESL Student Writing. Journal of Second Language Writing, 14(3), 191-205. https://doi.org/10.1016/j.jslw.2005.08.001

Botelho de Magalhaes, M., Cotterall, S., \& Mideros, D. (2019). Identity, voice and agency in two EAL doctoral writing contexts. Journal of Second Language Writing, 43, 4-14. https://doi.org/10.1016/j.jslw.2018.05.001

Cargill, M., Gao, X., Wang, X., \& O'Connor, P. (2018). Preparing Chinese graduate students of science facing an international publication requirement for graduation: Adapting an intensive workshop approach for early-candidature use. English for Specific Purposes, 52, 13-26. https://doi.org/10.1016/j.esp.2018.05.002

Chandler, J. (2003). The efficacy of various kinds of error feedback for improvement in the accuracy and fluency of L2 student writing. Journal of Second Language Writing, 12, 267-296. https://doi.org/10.1016/S1060-3743(03)00038-9

Choi, J. (2015). A Heritage Language Learner's Literacy Practices in a Korean Language Course in a U.S. University: From a Multiliteracies Perspective. Journal of Language and Literacy Education (JoLLe), 11(2), 116-133. 
Clark, R., \& Ivani`c, R. (1997). The politics of writing. New York/London: Routledge.

Cooper, P. R., \& Davis, D. A. (2016). Using writing as therapy: Finding identity-an evaluation of its effects upon clinical outcomes and service. International Journal of Therapy and Rehabilitation, 23(2), 64-74. https://doi.org/10.12968/ijtr.2016.23.2.64

Cotterall, S. (2015). The rich get richer: International doctoral candidates and scholarly identity. Innovations in Education and Teaching International, 52(4), 360-370. https://doi.org/10.1080/14703297.2013.839124

Dehghan, F., \& Razmjo, S. A. (2017). Developing a model for disciplinary writing expertise in postgraduate teaching English as a foreign language programs. Journal of Modern Research in English Language Studies, 4(4), 122-103.

Ellis, N. C. (2007). Dynamic systems and SLA: The wood and the trees. Bilingualism: Language and Cognition, 10(1), 23-25. https://doi.org/10.1017/S1366728906002744

Ellis, R., Sheen, Y., Murakami, M., \& Takashima, H. (2008). The effects of focused and unfocused written corrective feedback in an English as a foreign language context. System, 36, 353-371. https://doi.org/10.1016/j.system.2008.02.001

Farid, S., \& Abdul Samad, A. (2012). Effects of Different Kind of Direct Feedback on Student's Writing. Procedia, 66, 232-239. https://doi.org/10.1016/j.sbspro.2012.11.265

Ferris, D. (1997). The influence of teacher commentary on student revision. TESOL Quarterly, 31, 315-37. https://doi.org/10.2307/3588049

Ferris, D. R. (2014). Responding to student writing: Teachers' philosophies and practices. Assessing Writing, 19, 6-23. https://doi.org/10.1016/j.asw.2013.09.004

Ferris, D. R., \& Helt, M. (2000). Was Truscott right? New evidence on the effects of error correction in L2 writing classes. Paper presented at AAAL Conference, Vancouver, B.C., Canada.

Ferris, D. R., \& Roberts, B. J. (2001). Error feedback in L2 writing classes: How explicit does it need to be? Journal of Second Language Writing, 10, 161-184. https://doi.org/10.1016/S1060-3743(01)00039-X

Gómez-Estern, B. M., Amián, J. G., Sánchez Medina, J. A., \& Marco Macarro, M. J. (2010). Literacy and the Formation of Cultural Identity. Theory \& Psychology, 20(2), 231-250. https://doi.org/10.1177/0959354309345638

Groves, M., \& Mundt, K. (2015). Friend or foe? Google Translate in language for academic purposes. English for Specific Purposes, 37, 112-121. https://doi.org/10.1016/j.esp.2014.09.001

Huang, J. C. (2010). Publishing and learning writing for publication in English: Perspectives of NNES PhD students in science. Journal of English for Academic Purposes, 9(1), 33-44. https://doi.org/10.1016/j.jeap.2009.10.001

Hyland, K. (2013). Faculty feedback: Perceptions and practices in L2 disciplinary writing. Journal of Second Language Writing, 22, 240-253. https://doi.org/10.1016/j.jslw.2013.03.003

Ivani`c, R. (1998). Writing and identity. The discoursal construction of identity in academic writing. Amsterdam/Philadelphia: John Benjamins. https://doi.org/10.1075/swll.5

Kepner, C. G. (1991). An experiment in the relationship of types of written feedback to the development of second-language writing skills. Modern Language Journal, 5, 305-313. https://doi.org/10.1111/j.1540-4781.1991.tb05359.x

Kevin Yet Fong Cheung, James Elander, Edward James Nairn Stupple \& Michael Flay. (2016). Academics' understandings of the authorial academic writer: a qualitative analysis of authorial identity. Studies in Higher Education, 43(8), 1468-1483. https://doi.org/10.1080/03075079.2016.1264382

Kotamjani, S. S., \& Hussin, H. (2017). Perceptions of Challenges in Writing Academically: Iranian Postgraduate Students' Perspectives. International Journal of Applied Linguistics and English Literature, 6(4), 1-4. https://doi.org/10.7575/aiac.ijalel.v.6n.4p.1

Lalande, J. F. (1982). Reducing composition errors: An experiment. Modern Language Journal, 66(2), 140-149. https://doi.org/10.1111/j.1540-4781.1982.tb06973.x

Leggette, Holli R., \& Holly. J. (2017). How students develop skills and identity in an agricultural communications writing course. Journal of Applied Communications, 99(1), 38-51. https://doi.org/10.4148/1051-0834.1039 
Li, Y. (2016). "Publish SCI papers or no degree": Practices of Chinese doctoral supervisors in response to the publication pressure on science students. Asia Pacific Journal of Education, 36(4), 545-558. https://doi.org/10.1080/02188791.2015.1005050

Mahfoodh, O. H. A., \& Pandian, A. (2011). A qualitative case study of EFL students' affective reactions to and perceptions of their teachers' written feedback. English Language Teaching, 4, 14-27. https://doi.org/10.5539/elt.v4n3p14

McLaughlin, B. (1990). Restructuring. Applied Linguistics, 11, 113-128. https://doi.org/10.1093/applin/11.2.113

Perkins, M., Gezgin, U. B., \& Roe, J. (2018). Understanding the relationship between language ability and plagiarism in non-native English speaking business students. Journal of Academic Ethics, 16(4), 317-328. https://doi.org/10.1007/s10805-018-9311-8

Polio, C., Fleck, C., \& Leder, N. (1998). "If only I had more time": ESL learners' changes in linguistic accuracy on essay revisions. Journal of Second Language Writing, 7, 43-68. https://doi.org/10.1016/S1060-3743(98)90005-4

Robb, T., Ross, S., \& Shortreed, I. (1986). Salience of feedback on error and its effect on EFL writing quality. TESOL Quarterly, 20, 83-93. https://doi.org/10.2307/3586390

Robinson, S., Pope, D., \& Holyoak, L. (2013). Can we meet their expectations? Experiences and perceptions of feedback in first year undergraduate students. Assessment \& Evaluation in Higher Education, 38, 260-272. https://doi.org/10.1080/02602938.2011.629291

Russell, J., \& Spada, N. (2006). The effectiveness of corrective feedback for the acquisition of L2 grammar: A meta-analysis of the research. In J. Norris \& L. Ortega (Eds.), Synthesising research on language learning and teaching (pp. 133-164). Amsterdam: John Benjamins. https://doi.org/10.1075/1llt.13.09val

Sheen, Y. (2007). The effect of focused written corrective feedback and language aptitude on ESL learners' acquisition of articles. TESOL Quarterly, 41(2), 255-283. https://doi.org/10.1002/j.1545-7249.2007.tb00059.x

Swales, J. M. (1990). Genre analysis: English in academic and research settings. Cambridge, United Kingdom: Cambridge University Press.

Swales, J. M. (2004). Research genres: Explorations and applications. Cambridge, UK: Cambridge University Press. https://doi.org/10.1017/CBO9781139524827

Truscott, J. (1996). The case against grammar correction in L2 writing classes. Language Learning, 46, 327-369. https://doi.org/10.1111/j.1467-1770.1996.tb01238.x

Truscott, J. (1999). The case for "the case for grammar correction in L2 writing classes": A response to Ferris. Journal of Second Language Writing, 8, 111-122. https://doi.org/10.1016/S1060-3743(99)80124-6

Truscott, J. (2004). Evidence and conjecture: A response to Chandler. Journal of Second Language Writing, 13, 337-343. https://doi.org/10.1016/j.jslw.2004.05.002

Truscott, J. (2007). The effect of error correction on learners' ability to write accurately. Journal of Second Language Writing, 16, 255-272. https://doi.org/10.1016/j.jslw.2007.06.003

Truscott, J. (2009). Arguments and appearances: A response to Chandler. Journal of Second Language Writing, 18, 59-60. https://doi.org/10.1016/j.jslw.2008.09.001

Uysal, H. H. (2010). A critical review of the IELTS writing test. ELT Journal, 64(3), 314-320. https://doi.org/10.1093/elt/ccp026

Van Beuningen, C., De Jong, N., \& Kuiken, F. (2012). Evidence on the effectiveness of comprehensive error correction in second language writing. Language Learning, 62, 1-41. https://doi.org/10.1111/j.1467-9922.2011.00674.x

\section{Copyrights}

Copyright for this article is retained by the author(s), with first publication rights granted to the journal.

This is an open-access article distributed under the terms and conditions of the Creative Commons Attribution license (http://creativecommons.org/licenses/by/4.0/). 